\title{
The Role of Mentoring in Digital Literacy Development of Doctoral Students at British Universities
}

\author{
Elena Soltovets ${ }^{1 *}$, Oxana Chigisheva ${ }^{1}$, Anna Dmitrova ${ }^{1}$ \\ ${ }^{1}$ Southern Federal University, Rostov-on-Don, RUSSIA
}

Received 8 June 2019 • Revised 24 October 2019 • Accepted 25 November 2019

\begin{abstract}
The relevance of the study is due to the global digitalization and search for tools and practices fostering the process of doctoral students' training for independent quality research using the full range of available digital tools. Digital skills require continuous improvement. Thus, this article is aimed at identifying the possibilities of using mentoring for digital literacy development of British PhDs. Using comparison and terminological analysis the research considers the changing phenomenon of mentoring under the influence of information and digital transformations, identifies important digital skills being developed by doctoral students in the process of mastering the programs offered by UK university libraries. It is also justified that today librarians serve as mentors and can effectively develop digital literacy of doctoral students. The materials are valuable for doctoral students, teachers, mentors, academic librarians who provide professional development programs for researchers working with digital research tools.
\end{abstract}

Keywords: British universities, digital age, digital literacy, doctoral students, information literacy, mentoring

\section{INTRODUCTION}

Educational systems worldwide are dramatically changing both in relation to the structural, content and organizational requirements to the educational process and its methodological and methodical support. The problems of the first-stage education have been given much rigorous research over the last decades (Gibson et al., 2019; Kopish, 2016; Ryabchenko et al., 2018; Meehan \& Howells, 2019). The issues of post-graduate teaching strategies, however, have enjoyed less attention in terms of techniques and mentoring practices (Pavlíková, 2018). Though public debates on the challenges related to the quality of would-be scientists' training can hardly be called few (Aarnikoivu et al., 2019; Maer-Matei et al., 2019; Nicholas et al., 2019).

The fact that tertiary institutional machinery is characterized by certain intrinsic procedure-driven inertia adds to the complexity of the issue. Formal education structures in some countries rely heavily on traditional prerequisites and bureaucratic indicators in managing the process of doctoral training and research impact evaluation (Chigisheva, Soltovets \& Bondarenko, 2017; Strielkowski \& Chigisheva, 2018; Zaitseva et al., 2017). Changes in the training courses' fabric do not come easy and are rarely seen as vital by administrative staff who are reluctant (or, sometimes, unable) to introduce significant alterations in syllabus design to make it tailored to real-life demands. Moreover, gaining one's research expertise tends to be seen as a field of self-development, rather than a ground for focused training within the course of study. Hence, teaching process is reduced to conventional practices within the "supervised autonomy" paradigm. In fact, PhD students often find themselves carefully navigated through academic practicalities, while feeling lost in many subtle issues their supervisors have neither time nor possibility to help with. Such academic environment paved the way for new forms of learners' guidance and fostering non-formal and informal mentorship trajectories.

(c) 2020 by the authors; licensee Modestum Ltd., UK. This article is an open access article distributed under the terms and conditions of the Creative Commons Attribution License (http://creativecommons.org/licenses/by/4.0/).

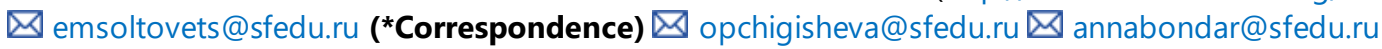




\section{Contribution of this paper to the literature}

- The study revealed that digitalization of teaching and research practices has contributed to the transformation of mentoring experience in terms of mentors' functions, communication patterns, mentormentee roles, focus and environment (formal and informal).

- The authors regard library staff of present-day universities as a new type of doctoral students' mentors in the areas of expertise related to developing digital literacy and mastering digital skills.

- The paper demonstrates a significant potential of mentoring services provided by the British university libraries for contributing to $\mathrm{PhD}$ students' research capacity when dealing with digital research environment.

Among the most commonly acknowledged mechanisms of such distributed support is the institute of mentorship. Thus, peer-mentoring, for instance, is being fondly cultivated by university management as an affordable and equally accessible tool (Hammersley, Waters \& Keefe, 2019; Quinlan et al., 2019). Mentoring has never become truly out-of-date in education, being practiced in one form or another within the classroom and beyond the academic setting. The idea of trusted advice and meaningful communication per se is the core of any pedagogical exercise. The very nature of the learning-intended partnership between those seeking knowledge and having vast experience in certain areas resonates with the concept of scientific research supervision. Therefore, various mentoring schemes can fit organically in the context of doctoral training, being potentially able to provide an easy fix to the formal teaching deficiencies. Their promise gains additional appeal with the spread of informal teaching agenda.

Nevertheless, third stage education system remains vulnerable in the situation when it has to keep the pace set by rapidly developing technology. There are increasingly numerous areas where familiar strategies fail. In terms of research mentoring the effect may become drastic. One of the most powerful drivers in this respect is endemic digitalization. New skills come into play shaping functional efficiency of a researcher. In this survival of the digitally fittest younger PhD students may seem to be in a privileged position of "digital natives". Digital literacy, the notion of which was introduced by Gilster (1997) as "the ability to understand and use information in multiple formats from a wide range of source when it is presented via computers" (p. 1), is still regarded as something inherently enjoyed by young researchers. But, as a matter of fact, they tend to feel intimidated by the complexity of the work ahead, including the necessity to select and analyze data. The world of Open Science is facing the challenge of being swept by the tidal wave of information, the problem unthinkable of just a few decades ago. What is more, the third stage of education is the time when students are considered to have been equipped with all necessary skills for a successful start of their research career. It comes as no surprise, then, that these circumstances make mentoring of the peers less meaningful. The role and essence of mentorship is thus needs to be actively redefined.

\section{THEORETICAL FRAMEWORK}

The notion of digital literacy is characterized by a wide variety of approaches when its essence, meaning and accurate definition are being considered. Trying to compartmentalize them, some scholars suggest building on the purport which can reveal diversity of the term's interpretations. Lankshear and Knobel (2006) distinguish two types of definitions given to the term: conceptual definitions of «digital literacy» (in broad sense) and standardized operationalizations of digital literacy (in narrow sense including certain sets of knowledge, skills, and tasks). Three key features have been identified as characteristic of most mainstream definitions: definitions confined to the roles played by information; epistemic engagement with information; definitions treating digital literacy «as an «It» - as some kind of a «thing»: a capacity or ability, a skill (or set of skills), or «master competency» (composed of more specific competencies and dispositions)» (Lankshear \& Knobel, 2006, p. 14-15).

List (2019) singles out three conceptions of digital literacy development accepted and used in the literature: digital literacy as an automatic process, digital literacy as a set of skills, sociocultural perspectives of digital literacy. The first group of digital literacy concepts roots in the works of Prensky (2001), who regarded students as digital natives, possessing inherent capability of handling digital information, unlike digital immigrants, i.e. those who try to develop this capacity as they had been born before the world became "digital". Prensky's works faced certain criticism. Some researchers point out that empirical evidence provided by Prensky is insufficient (Bennett, Maton \& Kervin, 2008). It is also argued that digital literacy can be inborn (Greene et al., 2018). Prensky's (2001) findings, though, are still referred to when concepts of digital literacy development are concerned. The second group of digital literacy concepts reviewed by List (2019) relates to the definition by Eshet-Alkalai (2004). According to it, «digital literacy involves more than the mere ability to use software or operate a digital device; it includes a large variety of complex cognitive, motor, sociological, and emotional skills, which users need in order to function effectively in digital environments» (Eshet-Alkalai, 2004, p. 93). Despite the fact that digital literacy embraces a wide range of skills, they are unable to make a detailed picture of how human behavior changes in the online 
environment when people are exposed to digital technologies. This has given rise to sociocultural concepts of digital literacy. Exploring social and cultural aspect of digital literacy development presented in these constructs, List (2019) points out that experience of communication in digital communities can contribute to shaping learners' digital literacy.

Following Chalkiadaki (2018), Martin and Grudziecki (2006), we interpret digital literacy as an ability to use digital technologies and tools for information search, analysis, evaluation, and transfer. We find it most suitable for reflecting the aspect of functional potential of a digitally literate person.

Martin and Grudziecki (2006) recognize three levels of digital literacy: digital competence (skills, concepts, approaches, attitudes), digital usage (application of digital competence within specific professional or domain contexts), digital transformation (achieved when the digital usages which have been developed enable innovation and creativity, and stimulate significant change within the professional or knowledge domain) (p.255).

A developmental model of effective E-learning, proposed by Sharpe and Beetham (2010), was implemented for developing digital literacy. The process has four levels: access, skills, practices, creative appropriation. At the first level the access to technologies, resources, and services is provided. The second level implies acquiring skills, e.g. instrumental or communicative. Then students learn how to use them in real-case scenarios. This shapes an ability to transform learning environment, which is the highest, fourth level. Thus, digital literacy development is described as an ongoing process, from learning skills to using them for changing one's surroundings by widening experience of educational, professional and everyday activities.

One more study conducted by Sharpe and Benfield (2012) revealed that British universities are currently placing great emphasis on teaching their students skills of dealing with digital tools. As stated in this research paper, teaching such skills is embedded into curricula of some British universities within the framework of blended learning programs (London Metropolitan University, Birkenhead Sixth Form College, Abingdon and Witney College). Informal ways of fostering practical skills are used as much as formal programs (University of Edinburgh). The study also showed that teaching digital skills is greatly assisted by librarians, who encourage students "to develop their personal practices e.g. allowing teaching sessions to be recorded, providing materials available for downloading to personal technology" (Sharpe \& Benfield, 2012, p. 9). Such advisory informal support is particularly important for doctoral students, as they need guidance in the use of digital technologies for authentic research and study tasks (Beetham, Littlejohn \& Milligan, 2012). So, mentors of this type become an important, or, rather, crucial component of the digital literacy development process when PhD training is concerned.

\section{METHODOLOGICAL FRAMEWORK}

\section{Research Purpose}

The purpose of this research study is to address the phenomenon of mentoring, being actively transformed in the digital age, demonstrate and evaluate its potential in developing digital literacy of PhD students through library support at British universities.

\section{Research Questions}

The following research questions were identified:

1. How is the institute of mentorship changing under the influence of digitalization when digital literacy skills are becoming critical for future researchers?

2. Can librarians be considered a new type of mentors directing and assisting British doctoral students in the process of digital literacy development? Do they suit the internationally recognized requirements to the mentor?

3. What skills related to digitalization of research are being most actively developed through mentoring support through of libraries and librarians at British universities?

\section{Research Objectives}

Research objectives were formulated in the logic of reaching the stated purpose and aimed at:

1. specifying the changing nature of the mentoring phenomenon in relation to the challenging digital reality transforming the sphere of science and research;

2. critical analysis of the library sector services in supporting British doctoral students in digital literacy development and defining whether this activity may be related to a new form of mentoring support;

3. identifying digital literacy skills targeted by library mentoring programs as crucial for efficient research. 
Table 1. Reference number and related university used in the study

\begin{tabular}{cc}
\hline Reference number & University \\
\hline 1 & University of Oxford \\
\hline 2 & University of Cambridge \\
\hline 3 & Imperial College London \\
\hline 4 & University College London \\
\hline 5 & University of Edinburgh \\
\hline 6 & University of Manchester \\
\hline 7 & King's College London \\
\hline 8 & University of Bristol \\
\hline 9 & University of Warwick \\
\hline 10 & University of Glasgow \\
\hline 11 & Durham University \\
\hline 12 & University of Sheffield \\
\hline 13 & University of Birmingham \\
\hline 14 & University of Nottingham \\
\hline 15 & University of Leeds \\
\hline 16 & University of Southampton \\
\hline 17 & University of St Andrews \\
\hline 18 & Queen Mary University of London \\
\hline 19 & Lancaster University \\
\hline 20 &
\end{tabular}

Source: the authors using Top 20 universities in the UK list (2019)

\section{Research Stages, Sample, Data Collection and Methods of Analysis}

The research study encompassed several stages. At the first stage we conducted a literature review of the mentoring phenomenon to trace the recent changes in its understanding under the influence of digitalization and spread of ICT; we also detected an increase in the number of library mentoring programs in information and digital literacy. At the second stage we chose top 20 universities in the UK (2019) from the QS World University Rankings 2019 (2019) as a sample. These are the most influential institutions both in the UK and worldwide. Thus, four of them appear in the global top 10 ranking, some others are included in global top 100. Table 1 shows the universities and related reference numbers used within the study.

Then, we addressed the library websites of all the chosen universities and carefully scanned their contents to collect data in relation to the activities (trainings, sessions, online courses, online services and instruments etc.) and supporting methodical tools (digital toolkits, plans, programs, guides etc.) offered for doctoral students and moderated by the academic support librarians. This analysis allowed to see a wide spectrum of activities impacting digital literacy development and using the criterion of "function" in relation to the roles and characters of mentors, relationship types, meeting mentees' needs and settings as represented at the website of the American Psychological Association in the "Introduction to Mentoring: A Guide for Mentors and Mentees" (2006) to categorize the activities of the librarians in this sphere as a new type of mentoring. At the third stage we dealt more deeply into digital skills being gained by $\mathrm{PhD}$ students of the top 20 British universities and classified most demanded areas of mentoring support provided by the library departments today.

In the process of research, we mainly used theoretical research methods, such as analysis, synthesis, generalization, comparison, categorization, classification and interpretation. The general reflexive function of the comparison allowed obtaining a perspective view of the phenomena and processes under study (Fedotova \& Chigisheva, 2015; Phillips \& Schweisfurth, 2014). The research was also supported by the terminological analysis that permitted highlighting the key transformations associated with information literacy, digital literacy and mentoring phenomena.

\section{RESULTS AND DISCUSSION}

\section{Changing Concept of Mentoring in the Digital Age}

Mentoring is broadly understood as an interaction between an individual having some expertise in the field (mentor) and an under-experienced person (mentee), when the latter enjoys professional advice and support in certain areas (Hudson, Usak \& Savran-Gencer, 2009, 2010; Muschallik \& Pull, 2015; Usak \& Masalimova, 2019, Yirci et al., 2016). So, it shows a traditional dichotomy «mentor - mentee». Other forms of mentoring are also possible, 
according to Meschitti, Smith and Panton (2014): peer mentoring; group mentoring; mentoring consortia. The scholars emphasize the value of group mentoring, when a few mentees form a group establishing communication with several mentors, which is particularly relevant for the «academic world that is increasingly competitive, changing and diverse» (p. 3). Doctoral training requires mentors who would spur their mentees' career development, rather than just equip them with gap-filling knowledge.

The scope of functions may reveal three main roles played by academic mentors:

- teacher (mentors communicate «technical knowledge», e.g. knowledge related to the research methodology, and «tacit knowledge», e.g. knowledge of academia or publishing processes);

- sponsor (mentors manage joint projects and create opportunities for PhD students in building cooperation or integrating into scientific commonwealth);

- collaborator (mentors provide the mentee "with both human and social capital») (Muschallik \& Pull, 2015).

These roles are performed during interpersonal (face-to-face) communication of mentors and mentee-students. Digitalization and spread of ICT gradually shift the balance towards e-mentoring, when communication is Internetassisted. «Career mentoring, traditionally conducted in-person, is now widely accessible online to help people navigate changes» (Tomprou et al., 2019, p. 563). Hamilton and Scandura (2003) consider e-mentoring as a threephase model. The stages they identify are as follows: initiation (ice-breaking, discussing needs, purposes and objectives, building technical infrastructure); cultivation (deploying mentoring programs); separation (reflection, progress review, and channeling mentoring into more person-oriented schemes). Online communities, chats, virtual environment platforms, forums can become powerful resources for e-mentoring practices.

Mentoring programs are widely viewed in academic discourse as formal vs. informal. They are differentiated by the following attributes: intensity (informal mentoring is generally viewed as much greater than the intensity of formal mentoring), visibility (informal mentoring often can be less visible than formal relationships), focus (most formal programs have organizationally prescribed goals, and the focus is on the mentee's professional; in contrast, informal mentoring is often driven by the needs of both parties, the goals of informal mentoring are often not articulated) and duration (it is regulated in formal programs in contrast to informal ones) (Chao, 2009, p. 315). Formal mentoring programs suggest having the third party represented by the university or any other organization providing mentoring support. It is notable that formal mentoring programs are more helpful for a young researcher's career development (Muschallik \& Pull, 2015). In this respect the research of 2012 by Brewerton (2012) on young professionals' needs in the changing environment of research careers is worth mentioning. The findings highlight increasing contribution of university library staff. It is noted that library mentoring programs proved helpful in introducing doctoral students to the research life cycle, while most of such programs involved learning how to search and manage relevant information.

\section{Librarian as a New Type of PhD Mentor in Digital Literacy}

Having in mind the traditional dichotomy of formal vs. informal relationships, giving birth to innumerable varieties of mentoring forms and settings, we focused on the types of relations evidenced in the analysis of documents published on the websites. Informal mentoring communication poses certain challenges for classification and description, especially for the outside observers not involved in the process. However, the opportunities of such contacts are apparent in most universities, as it can be seen from Tables 2 and 3. 
Table 2. Roles and characters of mentors

\begin{tabular}{|c|c|c|c|c|c|c|c|c|c|c|c|c|c|c|c|c|c|c|c|c|}
\hline $\begin{array}{c}\text { Roles and } \\
\text { characters of } \\
\text { mentors }\end{array}$ & 1 & 2 & 3 & 4 & 5 & 6 & 7 & 8 & 9 & 10 & 11 & 12 & 13 & 14 & 15 & 16 & 17 & 18 & 19 & 20 \\
\hline $\begin{array}{c}\text { Acts as an } \\
\text { experienced role } \\
\text { model }\end{array}$ & 0 & + & - & - & 0 & - & - & - & + & - & - & - & 0 & 0 & - & - & - & - & - & - \\
\hline $\begin{array}{c}\text { Provides acceptance, } \\
\text { encouragement, and } \\
\text { moral support }\end{array}$ & 0 & + & - & - & 0 & 0 & + & + & 0 & - & - & - & - & + & + & 0 & - & 0 & 0 & - \\
\hline $\begin{array}{c}\text { Provides wisdom, } \\
\text { advice, counsel, } \\
\text { coaching } \\
\end{array}$ & + & + & + & - & + & 0 & + & + & + & + & - & - & - & + & + & + & + & + & 0 & + \\
\hline $\begin{array}{l}\text { Acts as a sponsor in } \\
\text { professional } \\
\text { organizations, } \\
\text { supports networking } \\
\text { efforts } \\
\end{array}$ & - & - & - & + & - & - & - & - & - & 0 & - & - & - & - & 0 & - & - & - & 0 & - \\
\hline $\begin{array}{l}\text { Assists with the } \\
\text { navigation of } \\
\text { professional settings, } \\
\text { institutions, } \\
\text { structures, and } \\
\text { politics } \\
\end{array}$ & - & 0 & 0 & + & - & - & 0 & - & - & 0 & - & 0 & - & - & 0 & - & - & - & - & - \\
\hline $\begin{array}{c}\text { Facilitates } \\
\text { professional } \\
\text { development } \\
\end{array}$ & + & + & + & + & + & + & + & + & + & + & + & + & + & + & + & + & + & + & + & + \\
\hline $\begin{array}{c}\text { Provides } \\
\text { nourishment, caring, } \\
\text { and protection }\end{array}$ & - & + & - & - & - & - & 0 & - & + & - & - & 0 & - & 0 & + & - & - & - & - & - \\
\hline $\begin{array}{c}\text { Integrates } \\
\text { professional support } \\
\text { with other areas } \\
\text { such as faith, family, } \\
\text { and community }\end{array}$ & + & - & - & - & - & - & - & - & + & + & - & - & 0 & - & - & - & - & - & - & - \\
\hline $\begin{array}{l}\text { Accepts assistance } \\
\text { from mentee in } \\
\text { mentor's } \\
\text { professional } \\
\text { responsibilities } \\
\text { within appropriate } \\
\text { limits }\end{array}$ & - & - & - & - & - & + & - & 0 & 0 & - & - & - & - & 0 & 0 & - & - & - & - & - \\
\hline $\begin{array}{l}\text { Enjoys the } \\
\text { opportunity to pass } \\
\text { on their wisdom and } \\
\text { knowledge and } \\
\text { collaboration with } \\
\text { early career } \\
\text { professionals }\end{array}$ & + & 0 & 0 & - & + & 0 & - & + & 0 & 0 & 0 & - & - & + & 0 & 0 & 0 & 0 & - & - \\
\hline
\end{tabular}

Note: refer to Table 1 concerning the university and related number; "+" - evidence found in the data collected; "-" - evidence not found in the data collected; " 0 "- open-access information provided by the institution is not sufficient.

Source: the authors using academic library websites of Top 20 universities in the UK (2019)

Meetings, informal discussions, chats or personal talks can be available on request, booked by an individual or reserved for a group, related to specific research problems or common stumbling blocks. 
Table 3. Relationship types

\begin{tabular}{|c|c|c|c|c|c|c|c|c|c|c|c|c|c|c|c|c|c|c|c|c|}
\hline $\begin{array}{c}\text { Relationship } \\
\text { types }\end{array}$ & 1 & 2 & 3 & 4 & 5 & 6 & 7 & 8 & 9 & 10 & 11 & 12 & 13 & 14 & 15 & 16 & 17 & 18 & 19 & 20 \\
\hline $\begin{array}{l}\text { Established career } \\
\text { and early career }\end{array}$ & + & + & + & + & + & + & + & + & + & + & + & + & + & + & + & + & + & + & + & + \\
\hline $\begin{array}{c}\text { Professor to } \\
\text { student }\end{array}$ & 0 & + & + & - & + & + & + & + & + & + & + & + & + & + & 0 & 0 & 0 & 0 & 0 & - \\
\hline $\begin{array}{c}\text { Professional to } \\
\text { professional }\end{array}$ & + & + & + & + & + & + & + & + & + & + & + & 0 & 0 & + & + & + & + & + & + & + \\
\hline Peer mentoring & + & 0 & 0 & - & 0 & 0 & 0 & 0 & + & 0 & - & 0 & 0 & 0 & + & 0 & - & - & - & - \\
\hline $\begin{array}{c}\text { Collegial } \\
\text { collaborations }\end{array}$ & + & + & + & 0 & + & + & + & + & + & + & + & 0 & + & 0 & + & + & 0 & + & + & + \\
\hline Task-focused & + & + & + & + & + & + & + & + & + & + & + & + & + & + & + & + & + & + & 0 & + \\
\hline Regular contact & + & 0 & + & - & + & + & + & + & + & + & + & + & + & + & 0 & 0 & 0 & - & - & - \\
\hline Sporadic contacts & + & + & + & + & + & + & + & + & + & + & + & + & + & + & + & + & + & + & + & + \\
\hline Person-to-person & + & + & + & + & + & + & + & + & + & + & + & + & 0 & + & + & + & + & + & + & + \\
\hline Person-to-group & + & + & + & 0 & + & + & + & + & + & + & + & + & + & 0 & 0 & + & 0 & 0 & + & - \\
\hline
\end{tabular}

Note: refer to Table 1 concerning the university and related number; "+" - evidence found in the data collected; "-" - evidence

not found in the data collected; " 0 "- open-access information provided by the institution is not sufficient.

Source: the authors using academic library websites of Top 20 universities in the UK (2019)

Some institutions tend to create a relaxing atmosphere for the mentees, providing them with some kind of "warming up and nourishment", both literally and figuratively (see Table 2). The frequency of contacts and arrangement procedures vary greatly from bespoke sessions booked weeks beforehand to quick drop-ins. In most cases tailored guidelines and needs-specific advice are offered in a face-to-face regime.

Regular contacts, however, tend to rather be managed through mentor-group interaction, with most librarians leaning toward covering series of questions through a range of workshops on broader issues (as obvious from Table 4). Among the most popular were those related to information search, sources and data evaluation, research planning, referencing and citation skills, and increasing online visibility. As shown in Table 1, the needs of early career researchers are catered for by vast majority institutions. Surprisingly, ethical standards and moral norms of responsible research were not seen as an indispensable component of the skills package to equip a would-be researcher. Whether this fact can be explained by the formal training content might require further investigation. Among the most popular areas of concern or possible uncertainty were the following topics: avoiding plagiarism, ensuring academic integrity, combating malpractices, acknowledging copyright and intellectual property.

Another finding worth noting is the lack of any apparent evidence of facilitating early career researchers in institutions and structures in their professional field (Table 4). Despite claims to keep close contacts with the university departments, library staff does not advertise any events or activities that can possibly raise mentees' academic awareness in terms of policies, settings, and structures. While separate issues of career development are touched upon, the assistance is mostly focused on developing instrumental skills related to research collating, publishing and referencing practicalities. 
Table 4. Meeting mentees' needs

\begin{tabular}{|c|c|c|c|c|c|c|c|c|c|c|c|c|c|c|c|c|c|c|c|c|}
\hline Mentees' needs & 1 & 2 & 3 & 4 & 5 & 6 & 7 & 8 & 9 & 10 & 11 & 12 & 13 & 14 & 15 & 16 & 17 & 18 & 19 & 20 \\
\hline $\begin{array}{l}\text { Guidance in a } \\
\text { general or } \\
\text { specific } \\
\text { professional area }\end{array}$ & + & + & + & + & + & + & + & + & + & + & + & + & + & + & + & + & + & + & 0 & 0 \\
\hline $\begin{array}{c}\text { Series of } \\
\text { questions or } \\
\text { issues }\end{array}$ & + & 0 & + & + & + & + & + & 0 & + & + & + & 0 & + & 0 & - & - & - & 0 & 0 & - \\
\hline $\begin{array}{l}\text { Broad career } \\
\text { development }\end{array}$ & 0 & + & 0 & + & 0 & + & + & + & + & + & + & 0 & + & + & + & - & - & - & - & - \\
\hline $\begin{array}{c}\text { Early career } \\
\text { development }\end{array}$ & + & + & + & + & + & + & + & + & + & + & + & + & + & + & + & + & + & 0 & + & 0 \\
\hline $\begin{array}{l}\text { Ethical and moral } \\
\text { guidance }\end{array}$ & - & + & + & - & - & + & + & 0 & + & + & + & + & + & 0 & + & - & 0 & - & - & - \\
\hline $\begin{array}{c}\text { Assistance in } \\
\text { navigating } \\
\text { professional } \\
\text { settings, } \\
\text { institutions, } \\
\text { structures, and } \\
\text { politics } \\
\end{array}$ & - & 0 & - & + & - & 0 & - & 0 & - & 0 & 0 & - & - & - & 0 & - & - & - & - & - \\
\hline $\begin{array}{l}\text { Professional } \\
\text { identity } \\
\text { development } \\
\text { guidance } \\
\end{array}$ & 0 & - & - & - & - & 0 & 0 & + & 0 & 0 & 0 & - & 0 & - & + & 0 & - & - & - & - \\
\hline
\end{tabular}

Note: refer to Table 1 concerning the university and related number; "+" - evidence found in the data collected; "-" - evidence not found in the data collected; "0"- open-access information provided by the institution is not sufficient.

Source: the authors using academic library websites of Top 20 universities in the UK (2019)

The situations of interpersonal face-to-face communication could only be evaluated indirectly through analysis of the corresponding sections of the library support schemes advertised on the universities' websites. So, the positions implying intimate counseling and heart-to-heart encouragements seem underrepresented, according to Table 2. Moreover, the situations where librarians can serve as role models are generally confined to nonprofessional issues, as a librarian has to deal with a wide range of science fields. This role is rather played by the learners' supervisors. Another "weak" aspect of mentor-mentee communication was mentees' assistance (Table 2), as it was hardly mentioned in the learners-oriented programs. Naturally, peer mentoring was found in just a few of the library events (as it is clearly shown in Table 3) related to researchers' support and is not expected to form the mentoring domain in this respect. The role of a professional providing friendly guidance and giving expert's advice is much more enjoyed by library staff, according to the findings illustrated by Table 3. Regardless of the setting and environment, library mentoring services tend to fall into the categories of "professor to students" or "professional to professional". Collegial collaboration seems to form the purpose of some sessions and activities hold at the premises of the university libraries. Collaborative nature of mentoring initiatives is consistently emphasized. Collegial collaboration is also interpreted as willingness to work in partnership with academic staff that adds to the flexibility of mentoring support schemes. According to the promo information published on the official websites, a tailored approach is taken to develop and deliver resources which embeds information and digital skills in the course of study. Somewhat curiously, the message often seems to address teachers and supervisors, rather than learners. The "top-down" manner is felt in offering departments library services to suite their teaching needs. The trend of introducing online courses or records of workshops as freely-available self-study resources on frequently demanded queries should also be noted. An apparent trend towards blended learning can loose the bonds of teaching instrumental skills and set mentors free for in-depth guidance and informal interaction through encouraging discussions. Despite the fact that no direct correlation was found between the number of online "one-size-fits-all" resources (including open-access courses, workshops, tutorials, toolkits) provided by the institution and availability of in-person contacts, a tendency of introducing informal one-to-ones was observed in the majority of cases (Table 3 ).

There is also a clearly marked diversification of contact means, types and settings (as illustrated by Tables 3 and 5). 
Table 5. Settings

\begin{tabular}{cccccccccccccccccccccc}
\hline Settings & $\mathbf{1}$ & $\mathbf{2}$ & $\mathbf{3}$ & $\mathbf{4}$ & $\mathbf{5}$ & $\mathbf{6}$ & $\mathbf{7}$ & $\mathbf{8}$ & $\mathbf{9}$ & $\mathbf{1 0}$ & $\mathbf{1 1}$ & $\mathbf{1 2}$ & $\mathbf{1 3}$ & $\mathbf{1 4}$ & $\mathbf{1 5}$ & $\mathbf{1 6}$ & $\mathbf{1 7}$ & $\mathbf{1 8}$ & $\mathbf{1 9}$ & $\mathbf{2 0}$ \\
\hline $\begin{array}{c}\text { Professional } \\
\text { settings }\end{array}$ & + & + & + & + & + & + & + & + & + & + & + & + & + & + & + & + & + & + & + & + \\
\hline $\begin{array}{c}\text { Organizations } \\
\text { (e.g., APA) }\end{array}$ & - & - & - & + & - & - & 0 & - & - & - & - & - & 0 & - & - & - & - & - & - & - \\
\hline \begin{tabular}{c} 
Community \\
\hline nternet, email, \\
telephone
\end{tabular}$+$ & + & + & - & + & + & + & + & 0 & + & + & 0 & - & + & 0 & + & 0 & - & - & - & - \\
\hline $\begin{array}{c}\text { Informal national } \\
\text { and international } \\
\text { networks within } \\
\text { specialties }\end{array}$ & + & 0 & 0 & - & 0 & + & + & - & - & - & 0 & 0 & - & + & 0 & - & - & - & - & - \\
\hline
\end{tabular}

Note: refer to Table 1 concerning the university and related number; " +" - evidence found in the data collected; "-" - evidence not found in the data collected; "0"- open-access information provided by the institution is not sufficient.

Source: the authors using academic library websites of Top 20 universities in the UK (2019).

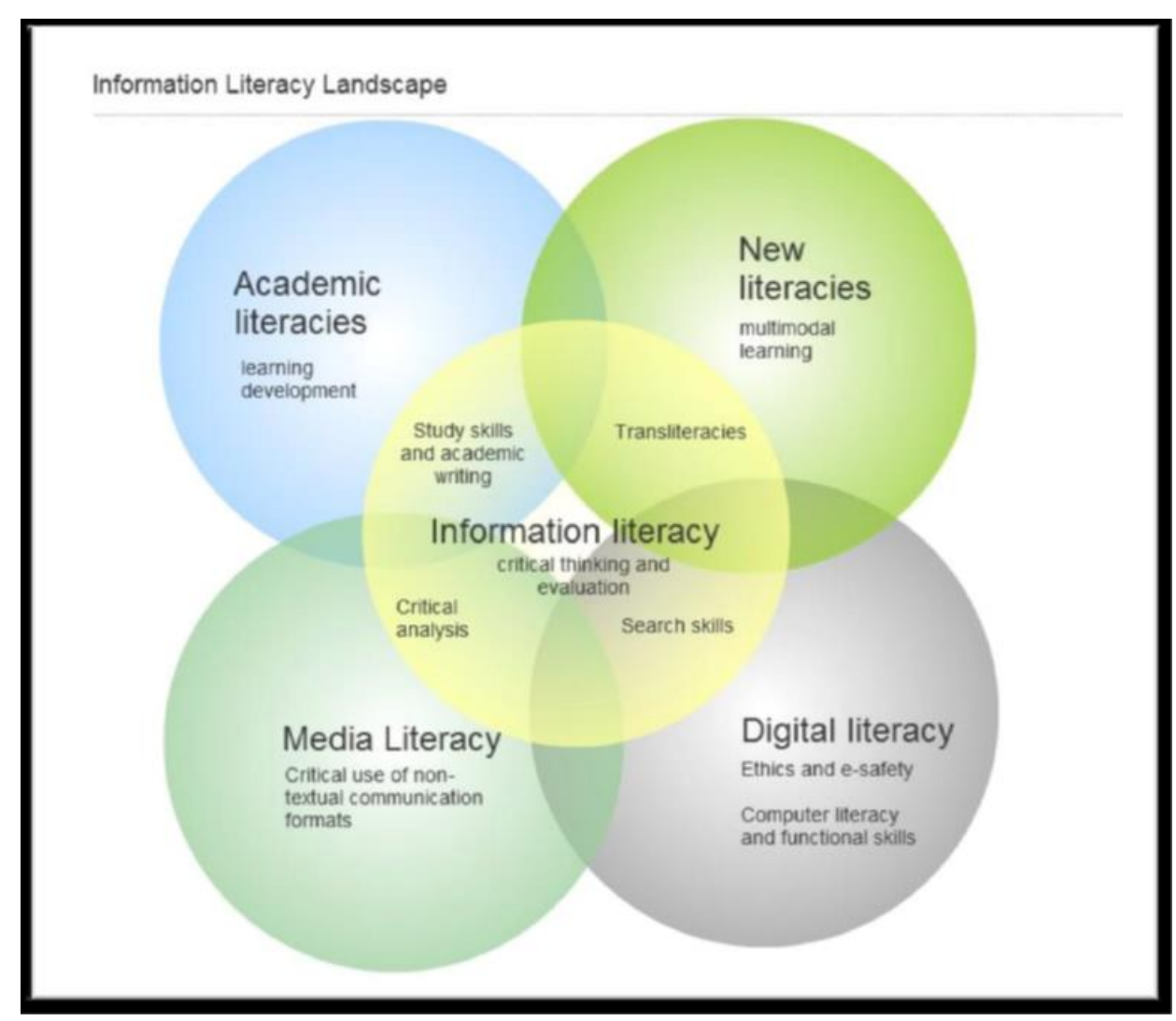

Figure 1. Information literacy landscape

As far as settings are concerned, IT-assisted communication is quite expectedly ubiquitous. On the contrary, networking (whether understood as social media or web of professional links) was far less visible (see Table 5). Group mentoring experience does not prove to help learners integrate into larger academic structures or relate to professional communities.

\section{Areas of Mentoring Support in Digital Literacy at PhD Level}

The landscape of information literacy is also significantly changing with the growth of information loads resulting in the need to develop "fluency" in different types of literacies for successful research career growth. Figure 1 offered by Secker and Coonan (2013) vividly demonstrates the overlaps between information literacy and digital literacy that are essential for the successful digital literacy development by doctoral students in both formal and lifelong learning. 


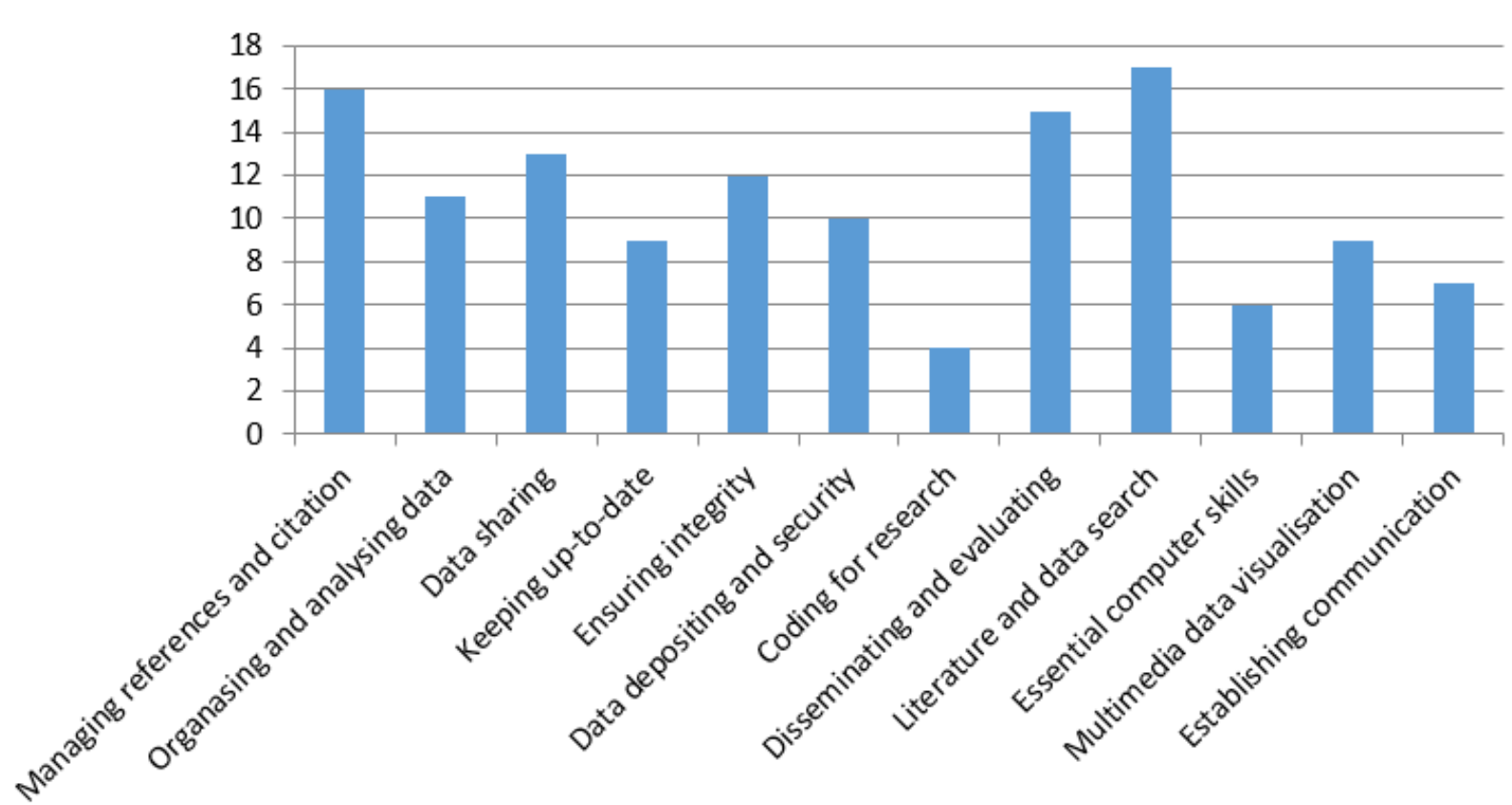

Figure 2. Areas of mentoring support provided by the library departments of the Top 20 British universities Source: the authors

The overlaps between information and digital literacy occur mostly in relation to search skills that imply good command of computer literacy and functional skills accompanied by the knowledge of ethics and e-safety mechanisms. At the same time, focus on critical thinking and evaluation is at the core of all activities related to digital literacy development regardless of the narrow implementation of the digital skills being gained.

Such is the principle assumption underlying the teaching and mentoring support offered by the British universities' library departments. As apparent from Figure 2, among the skills most commonly targeted by the library staff are those relevant for searching, handling and evaluating research-specific information. Meanwhile, instrumental computer skills are given less attention overall.

It might be informative to have a closer look at the bigger picture of products and skills being addressed. The positions are listed in the ranking order from the most to the least popular. The skills necessary for searching literature and mining research data are obviously most commonly considered crucial for the researcher, according to the number of universities offering guidance and support on the matter. The content of the mentoring sessions can be subject-specific or of general principle character.

The know-hows of dealing with bibliographic references and managing citation ratio are ranking second in importance. Referencing software programs like EndNote, Mendelay, Zotero are often mentioned in the list of products to be aware of. Of almost equal importance are the skills associated with disseminating and evaluating research through:

- bibliometrics (citation metrics such as average times cited, h-index and journal impact factors.) These resources comprise Web of Science (including Web of Science Core Collection, Journal Citation Reports, Essential Science Indicators, Biosis, InCites) and Scopus;

- unique author identifiers, such as ORCID and ResearcherID.

Data sharing infers open access publishing and sharing findings online outside of the institutional repository to possibly raise the profile of the young researchers and increase the level of exposure (https://www.library.qmul.ac.uk/research/theses/sharing-your-thesis/). These include dealing with various repositories, data centers, journals, web-based tools like Figshare, ResearchGate, Academia.edu etc.

Ensuring integrity is another area of popular mentors' concern. It encompasses a number of issues related to raising plagiarism awareness, learning copyright for researchers, rules of intellectual property (Intellectual Property Rights, Creative Commons and model licenses to publish). Organizing and analyzing data using pivot tables or statistical software (e.g., Excel, Matlab, Stata) is also seen as a necessary prerequisite for a researcher regardless of the field of study. Security issues are often linked to the skills of digital data depositing (ORA-data, cloud storage services) and addressed through a number of events, apart from numerous tutorials and how-to guides. 
The mentees are also expected to keep themselves up-to-date in the rapidly changing field of academic competition. So, the library staff offers a wide range of services on potentially helpful methods and techniques of being informed. They might include alerts by e-mail, RSS-feeds, social media like Mendeley, professional networking websites like ResearchGate and Academia, as well as general web alerting services that help to monitor new or changing content on websites (e.g. Google Alerts, Yahoo Alerts, and ChangeDetection). Generic conference alert services are also mentioned as widely available (e.g. AllConferences.com and Conference Alerts.).

Instrumental skills for building interactive content through multimedia tools and data visualization is the following position catered for by 9 out of 20 universities. The software used for that aim can vary from PowerPoint presentations, through image editing systems (Gimp, Photoshop) to audio and video management. Communication in the academic community is supposed to be established through such networking tools as LinkedIn, Twitter, or blogging. Academic networking, though, does not require in-depth training, according to the number of programs mentioning this skill as crucial.

Two areas of concern left at the relevant periphery are directly related to instrumental computer skills. Essential computer skills must be tackled as having been developed by the previous professional experience or as an area of technical expertise. Coding for research (including html, CSS, Python etc.), on the contrary, is not commonly treated as a universally helpful ability, though the library staff highlights the fact it can be of equal use for sciences and humanities.

The sphere of functional computer skills is thus presented by various areas and shaped by specific goal-related requirements. However, they are not of the highest priority as far as mentee's needs are concerned. Informationprocessing skills within the area where digital literacy and information literacy overlap are enjoying the highest degree of attention and regarded as crucial for the researchers by the library staff in most universities.

\section{CONCLUSION}

The study of the documents provided on the websites of the Top 20 British universities allowed some conclusions on the mentoring policies of the library departments as to digital literacy is viewed and developed. The study proves that digitalization of the academic research has influenced researchers' training. The areas of demanded mentoring support have expanded to encompass the sphere of information and digital literacy. Developing digital skills is seen as crucial for young researchers' training in view of open access principles.

The role of library services in providing various forms of formal and informal guidance and counseling on request has demonstrated considerable similarity with mentoring function. University library staff provides researchers and leaners with assistance that can be categorized as mentoring support in what concerns their main roles, types of relationships established, settings and approaches to meet the needs of the mentees. Most actively developed digital skills lie in the borderline area between information and digital literacies and are primarily related to information search, evaluation and protection. This might suggest further emphasis on library mentoring support in the area of Open Science promotion and digital literacy development in the sphere of doctoral training. Diversification of types and kinds of tailored communication sessions and on-request support can be expected.

Among the limitations of the study one should note that it was found hard to evaluate the extent to which informal interaction individualizes mentoring practices. The only information accessible is often presented in truncated version which is easily explained by its formal status and complexity of verbalizing mentoring experience into some rigidly structured and commonly used activities. Thus, the nature and content of informal communication available for the universities' insiders were left beyond the scope of the research. Mentors' role is another sphere where document analysis can scarcely provide full clarification of the state of affairs de facto. Such entities as "protection", "moral support", or "wisdom" are really hard to consider in terms of quantitative assessment. With this said, further research of the issue might require in-depth analysis of mentoring practices on the spot.

\section{ACKNOWLEDGEMENTS}

The publication of this paper was financially supported by Southern Federal University, Rostov-on-Don, Russian Federation.

\section{REFERENCES}

Aarnikoivu, M., Nokkala, T., Siekkinen, T., Kuoppala, K., \& Pekkola, E. (2019). Working outside academia? Perceptions of early-career, fixed-term researchers on changing careers. European Journal of Higher Education, 9(2), 172-189. https:/ / doi.org/10.1080/21568235.2018.1548941 
Beetham, H., Littlejohn, A., \& Milligan, C. (2012). Digital literacies for the research institution. In R. Andrews, E. Borg, S. B. Davis, M. Domingo, \& J. England (Eds.), The SAGE handbook of digital dissertations and theses, (pp. 63-80). London: SAGE Publications. https:// doi.org/10.4135/9781446201039.n5

Bennett, S., Maton, K., \& Kervin, L. (2008). The 'digital natives' debate: A critical review of the evidence. British Journal of Educational Technology, 39(5), 775-786. https:/ / doi.org/10.1111/j.1467-8535.2007.00793.x

Brewerton, A. (2012). Re-skilling for research: investigating the needs of researchers and how library staff can best support them. New Review of Academic Librarianship, 18(1), 96-110. https:/ / doi.org/10.1080/13614533.2012.665718

Chalkiadaki, A. (2018). A systematic literature review of 21st century skills and competencies in primary education. International Journal of Instruction, 11(3), 1-16. https:/ / doi.org/10.12973/iji.2018.1131a

Chao, G. T. (2009). Formal mentoring: lessons learned from past practice. Professional Psychology: Research and Practice, 40(3), 314-320. https:// doi.org/10.1037/a0012658

Chigisheva, O., Soltovets, E., \& Bondarenko, A. (2017). Functional foreign language literacy for global research career development: Analysis of standardized open-ended interview responses. XLinguae, 10(4), 138-153. https:/ / doi.org/10.18355/XL.2017.10.04.12

Eshet-Alkalai, Y. (2004) Digital literacy: A conceptual framework for survival skills in the digital era. Journal of Educational Multimedia and Hypermedia, 13(1), 93-106.

Fedotova, O., \& Chigisheva, O. (2015). Comparative analysis: Methodological optics in the ideological context. International Perspectives on Education and Society, 26, 57-82. https://doi.org/10.1108/S1479367920140000026003

Gibson, S., Grace, A., O'Sullivan, C., \& Pritchard, C. (2019). Exploring transitions into the undergraduate university world using a student-centred framework. Teaching in Higher Education, 24(7), 819-833. https:/ / doi.org/10.1080/13562517.2018.1511538

Gilster, P. (1997). Digital literacy. New York: Wiley Computer Publications.

Greene, J. A., Copeland, D. Z., Deekens, V. M., \& Yu, S. B. (2018). Beyond knowledge: examining digital literacy's role in the acquisition of understanding in science. Computers $\mathcal{E}$ Education, 117, 141-159. https: / / doi.org/10.1016/j.compedu.2017.10.003

Hamilton, B. A., \& Scandura, T. A. (2003). E-Mentoring: implications for organizational learning and development in a wired world. Organizational Dynamics, 31(4), 388-402. https: / / doi.org/10.1016/S0090-2616(02)00128-6

Hammersley, J. J., Waters, M. L., \& Keefe, K. M. (2019). Use of peer mentoring, interdisciplinary collaboration, and archival datasets for engaging undergraduates in publishable research. Frontiers in Psychology, 10, 96-104. https://doi.org/10.3389/fpsyg.2019.00096

Hudson, P. B., Usak, M., \& Savran-Gencer, A. (2010). Benchmarking mentoring practices: A case study in Turkey. Eurasia Journal of Mathematics, Science and Technology Education, 6(4), 245-252. https://doi.org/10.12973/ejmste/75245

Hudson, P., Usak, M., \& Savran-Gencer, A. (2009). Employing the five-factor mentoring instrument: analysing mentoring practices for teaching primary science. European Journal of Teacher Education, 32(1), 63-74.

Introduction to Mentoring: A Guide for Mentors and Mentees. (2006). American Psychological Association. Retrieved from https: / /www.apa.org/education/grad/mentoring

Kopish, M. A. (2016). Preparing Globally Competent Teacher Candidates Through Cross-Cultural Experiential Learning. Journal of Social Studies Education Research, 7(2), 75-108.

Lankshear, C., \& Knobel, M. (2006). Digital literacies: policy, pedagogy and research considerations for education. Nordic Journal of Digital Literacy, 1(1), 12-24.

List, A. (2019). Defining digital literacy development: An examination of preservice teachers' beliefs. Computers $\mathcal{E}$ Education, 138, 146-158. https:// doi.org/10.1016/j.compedu.2019.03.009

Maer-Matei, M. M., Mocanu, C., Zamfir, A. M., \& Georgescu, T. M. (2019). Skill needs for early career researchersa text mining approach. Sustainability (Switzerland), 11(10), 2789. https:/ / doi.org/10.3390/su11102789

Martin, A., \& Grudziecki, J. (2006). DigEuLit: concepts and tools for digital literacy development. Innovations in Teaching and Learning in Information and Computer Sciences, 5(4), 1-19. https:/ / doi.org/10.11120/ital.2006.05040249

Meehan, C., \& Howells, K. (2019). In search of the feeling of 'belonging' in higher education: undergraduate students transition into higher education. Journal of Further and Higher Education, 43(10), 1376-1390. https://doi.org/10.1080/0309877X.2018.1490702 
Meschitti, V., Smith, H. L., \& Panton, M. (2014). Mentoring Handbook of Good Practice. Retrieved from http://www.bbk.ac.uk/trigger/docs/Mentoring_Handbook_of_Best_Practice-Web.pdf

Muschallik, J., \& Pull, K. (2015). Mentoring in higher education: does it enhance mentees' research productivity? Education Economics, 24(2), 210-223. https:// doi.org/10.1080/09645292.2014.997676

Nicholas, D., Watkinson, A., Boukacem-Zeghmouri, C., Rodríguez-Bravo, B., Xu, J., Abrizah, A., ... Herman, E. (2019). So, are early career researchers the harbingers of change? Learned Publishing, 32(3), 237-247. https:// doi.org/10.1002/leap.1232

Pavlíková, M. (2018) Kierkegaard's understanding of man and society. XLinguae, 11(1), 323-331. https:// doi.org/10.18355/XL.2018.11.01.27

Phillips, D., \& Schweisfurth, M. (2014). Comparative and International Education. An Introduction to Theory, Method, and Practice. London: Bloomsbury Continuum International Publishing Group. https: / / doi.org/10.1080/03050068.2013.871833

Prensky, M. (2001). Digital natives, digital immigrants part 1. On the Horizon, 9(5), 1-6. https: / / doi.org/10.1108/10748120110424816

Quinlan, E., Crowe, T., Deane, F. P., \& Whittington, M. E. (2019). Functions of peer mentoring, satisfaction and the "real" relationship in postgraduate psychology education. International Journal of Mentoring and Coaching in Education, 8(1), 52-68. https:/ / doi.org/10.1108/IJMCE-06-2018-0033

Ryabchenko, O. N., Prokopyev, A. I., Romanchenko, L. N., Korzhuev, A. V., \& Krokhina, J. A. (2018). Social and philosophical understanding of national and civic identity in the context of interethnic and interreligious conflict risks. XLinguae, 11(2), 359-369. https:/ / doi.org/10.18355/ XL.2018.11.02.29

Secker, J., \& Coonan, E. (2013). Rethinking Information Literacy: A Practical Framework for Supporting Learning. London: Facet Publishing.

Sharpe, R., \& Beetham, H. (2010). Understanding students' uses of technology for learning: towards creative appropriation'. In R. Sharpe, H. Beetham, \& S. de Freitas (Eds.), Rethinking learning for a digital age: how learners are shaping their own experience, (pp. 85-99). London: Routledge. https: / / doi.org/10.4324/9780203852064

Sharpe, R., \& Benfield, G. (2012). Institutional strategies for supporting learners in a digital age. Enhancing Learning in the Social Sciences, 4(2), 1-17. https:// doi.org/10.11120/elss.2012.04020004

Strielkowski, W., \& Chigisheva, O. (2018). Research functionality and academic publishing: Gaming with altmetrics in the digital age. Economics and Sociology, 11(4), 306-316. https:/ / doi.org/10.14254/2071-789X.2018/11-4/20

Tomprou, M., Dabbish, L., Kraut, R. E., \& Liu. F. (2019). Career Mentoring in Online Communities: Seeking and Receiving Advice from an Online Community. In ACM CHI Conference on Human Factors in Computing Systems, May 4-9, 2019, (paper 653, pp. 1-12). Glasgow, Scotland, UK. Retrieved from http:/ / www.fannieliu.com/ papers/ career-mentoring.pdf

Top 20 universities in the UK. (2019). Retrieved from https://www.topuniversities.com/university-rankingsarticles/world-university-rankings/top-universities-uk-2019

Usak, M., \& Masalimova, A. R. (2019). Mentoring on science teacher education in Russia and international perspectives. Journal of Baltic Science Education, 18(3), 320-322. https:// doi.org/10.33225/jbse/19.18.320

Yirci, R., Karakose, T., Uygun, H., \& Ozdemir, T. Y. (2016). Turkish Adaptation of the Mentorship Effectiveness Scale: A validity and Reliability Study. Eurasia Journal of Mathematics, Science and Technology Education, 12(4), 821-832. https: / / doi.org/10.12973/eurasia.2016.1440a

Zaitseva, N. A., Larionova, A. A., Gornostaeva, Z. V., Malinina, O. Y., Povalayeva, V. A., Vasenev, S. L., ... Ersozlu, A. (2017). Elaboration of the methodology for assessing the development of managerial competences in university students taught with the use of case-technologies. Eurasia Journal of Mathematics, Science and Technology Education, 13(11), 7339-7351. https:/ / doi.org/10.12973/ ejmste/79609

\section{http://www.ejmste.com}

